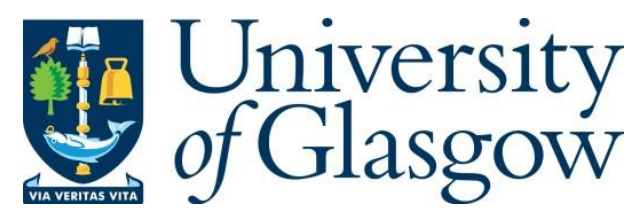

Goldoni, M. (2018) Assessing national parliaments after the Euro crisis: resignation, adaptation, and reaction. Politique europeenne, 59, pp. 218-230.

There may be differences between this version and the published version. You are advised to consult the publisher's version if you wish to cite from it.

http://eprints.gla.ac.uk/161973/

Deposited on: 9 May 2018

Enlighten - Research publications by members of the University of Glasgow http://eprints.gla.ac.uk 


\section{Review Article \\ Assessing National Parliaments after the Euro Crisis: Resignation, Adaptation, and Reaction}

\section{Marco Goldoni (Glasgow University)}

The academic interest for national parliaments (NPs) has not suffered from fatigue. To the contrary, academic research has become more and more sophisticated and, by now, has addressed a number of important issues concerning NPs. For a long time, research on the role (mostly legisprudential, but not limited to that) of NPs in the EU has been driven by two fundamental questions: how much can national parliaments affect EU policymaking and lawmaking and how much can they be Europeanised without losing the specificity of their own national functions? Yet, the Euro-crisis (one among many which have plagued the EU and its Member States in recent years), has reverted the question: how much Europeanisation can national parliaments endure before their capacity for autonomous political decision-making will be reduced to a minimum? The three volumes ${ }^{1}$ examined in this review article are driven mostly by the question posed by the subtitle of Maatsch's book: are national parliaments, in the context of the new Euro governance, still deliberative bodies or have they been reduced to talking shops? A variation of this question constitutes the subtitle of Jancic's edited volume as well: are we facing a case of resilience or resignation? The question is obviously and immediately relevant for the legitimacy and the functioning of both the EU and the national systems. The reason for the academic interest generated around national parliaments has to be seen in the common intuition that, among all European institutions, national parliaments are those that in virtue of (1) their own position and composition and (2) their own institutional preferences, are better positioned (at least within the EU) to subtract political action from the overdetermination of economic or financial forces. National parliaments remain the closer institutions to electoral constituencies and MPs are often constrained by the imperatives of being re-elected. The widespread assumption behind this is that national parliaments do have in-built incentives to be sensitive toward claims coming from society and less prone to serve as vectors of economic interests. In other words, NPs are the institutional channel whose politics is less prone to be coopted by non-political forces.

One should add that the ratification of the Lisbon Treaty, often defined as the Treaty of the Parliaments because it increased the number of parliamentary rights and competences (both of NPs and the European Parliament), seemed to open a new epoch of activism for parliamentary institutions in the EU. As Jancic appropriately sums up in the introductory chapter of his edited collection, 'the key post-Lisbon prerogatives [...] are to receive information on draft EU legislation and third-country applications for EU membership, to police the principle of subsidiarity, to monitor Europol's and Eurojust's activities, to participate in the revision of the Treaties, and to build tighter relations with the EP' (Jancic, p. 6). This list partially explains why in many disciplines the topic of the role of parliaments had taken up a new impetus. Unfortunately, the Treaty entered into force just before the

\footnotetext{
${ }^{1}$ The three volumes are: D. Jancic (ed), National Parliaments after the Lisbon Treaty and the Euro Crisis, Oxford University Press, Oxford, 2017 (hereafter: Jancic in parenthesis in the text); A. Maatsch, Parliaments and the Economic Governance of the European Union, Routledge, Abingdon, 2017; T. Winzen, Constitutional Preferences and Parliamentary Reform: Explaining National Parliaments' Adaptation to European Integration, Oxford University Press, Oxford, 2017 (hereafter: Winzen)
} 
inception of the Euro crisis and in the period between 2010 and 2012, several measures (at times approved via emergency or unconventional channels) ${ }^{2}$ were introduced, with the formal consent of parliaments, despite the fact that these same measures seemed to undercut parliaments' potential for genuine political decision-making. In addressing these problems, these three volumes show beyond any reasonable doubt that the community of research which have developed and flourished in the last decade around the study of national parliaments is ready to address them with a rich array of methodologies. ${ }^{3}$ Overall, the three volumes offer an enriching interpretation of the current transformation of national parliaments in the EU.

\section{National Parliaments Facing the Euro-Crisis}

In the last decade, the crisis and the ensuing array of new political and legal measures have undoubtedly changed the constitutional balance within the EU. ${ }^{4}$ Unavoidably, the new economic governance has put the position of (at least some) national parliaments under a lot of political and constitutional stress. In hindsight, it is impressive to observe how quickly the position of parliaments has substantially changed: from potential new protagonists of EU lawmaking (through subsidiarity review and the political dialogue) to (once again) victims of the new regime of European lawmaking, which has been properly defined as 'new intergovernmentalism'. ${ }^{5}$ While the Early Warning Mechanism for reviewing subsidiarity elicited a lot of interest in the first few years of its application as the main opportunity for involving national parliaments in the production of EU law, the new circumstances created by the multiple crises affecting the EU have clearly pushed research toward different directions. The interest seems now to be moving from participation into ordinary lawmaking to new forms of engagement with institutions well beyond the European Parliament and the Commission. In light of this consideration, the structure of the collection edited by Jancic strikes as appropriate. The first part is dedicated to the theory and history of national parliaments in European constitutionalism and contains chapters from some of the most prominent and original authors of the field (Besselink, Lindseth, Fasone and Lupo, Smith and Barrett), touching upon the issues of democratic or mediated legitimacy, the relation with judicial power and constitutional review or the impact of comitology and the Open Method of Coordination. Through this series of chapters we are offered an analytical overview on many levels of the complex relation between national parliaments and EU institutions. But it is with Part II and Part III that the volume takes up directly the challenge represented by what is defined by the editor as the 'crisis incentive'.

Part II is focussed on the impact of the new economic governance on national parliaments. What emerges out of the five chapters comprising this part is a new set of priorities for

\footnotetext{
2 For a reconstruction of the use of emergency powers as a tool for change see J. White, 'Emergency Europe', Political Studies, 2(63), 2015, 300-318.

${ }^{3}$ For an assessment of the state of the research on NPs, see the recent overview of the literature concerning the role of NPs in the EU see B. Crum, 'National Parliaments and Constitutional Transformation in the EU', European Constitutional Law Review, 4(13), 2017, pp. 817-835. The state of the art is now represented by the following encompassing research handbook: C. Neuhold, O. Rozenberg, J. Smith, C. Hefftler (eds), The Palgrave Handbook of National Parliaments and the EU, Palgrave, London, 2015.

${ }^{4}$ For an illuminating analysis see F. de Witte, M. Dawson, 'The Constitutional Balance of the Eu after', Modern Law Review, 5(76), 2013, pp. 817-844.

${ }^{5}$ On the rise of the new intergovernmentalism see U. Puetter, The European Council and the Council, Oxford University Press, Oxford, 2014.
} 
national parliaments. In his contribution, Ingolf Pernice provides an overview of the transformation of the economic governance and its impact upon notions of dialogue and cooperation among European institutions. Pernice shows how parliaments have been resigned to accept and often adopt new measures during the crisis which would deprive them of substantial capacity for action in the future. But he also remarks that some of these provisions, in particular the European Semester and the economic dialogue, might push national parliaments to take into account European aspects in their decisions and inject parliamentary legitimacy into forms of cooperation. His evaluation is that the jury is still out on the autonomy left to national parliaments because the latter can still find venues to remedy or contain the dominant new intergovernamentalism. A precious oversight of the accountability of the European Council and the Council is offered by Diane Fromage. She reviews the ability of the NPs of the five biggest Member States (UK, France, Germany, Italy, and Spain) to influence and hold their governments to account for their action in the European Council and the Council. Her analysis shows that over the years of the crisis, and bearing in mind that transparency and accountability are more problematic in the European Council rather than in the Council, political accountability of executive powers has become tighter in France, Italy, and Spain, while the UK and Germany have constantly ensured a flow of information to their parliaments. Fromage gives a relatively optimistic and at the same time realistic judgment on the performance of these parliamentary chambers. Realistic because it takes into consideration both the limits of the mandate-based system of political accountability, as a strict implementation would constrain the leverage for bargaining of the executive or move the decisionmaking process in informal arenas, and the difficulties of using extreme remedies (in particular, to remove the confidence to the government). Optimistic because, despite the shortage of sanctions in the hands of NPs, it finds them engaged in functioning as a transmission belt between its constituencies and the political intentions of the executive. Part and parcel of this effort is the attempt of striking a right balance between the communication function of parliamentary politics, mostly obtained in plenary sessions, and the scrutiny function, which is delegated to specialised committees. ${ }^{6}$

Frank Wendler's analysis expands on the latter point and it aims at showing that the management of the Eurozone crisis has modified rather than simply reduced the role of parliamentary politics. Wendler formalises this change by noting that 'while the government-related involvement of parliaments as scrutinizers and policy-making actors may have come under pressure, NPs have assumed a stronger citizen-related role as institutions representing political actors with dissenting views on the resolution of the crisis, and as arenas of public deliberation between these actors' (Jancic, p. 177). The chapter scrutinises three case studies (France, Germany and Austria) with particular attention to the form, structure and scope of plenary debates. Wendler's findings confirm Fromage's analysis because they show an increased debating activity in NPs. These three parliaments, although with different modalities (allowing for example, different spaces and timing to the parliamentary opposition) have served as arenas for structuring and organising the interaction between political actors such as government, parliamentary majorities and opposition parties.

Alexandra Maatsch takes up the question of compliance with the European Semester by NPs by assuming that this is intrinsically difficult as their institutional design 'does not allow

\footnotetext{
${ }^{6}$ Fromage highlights in particular the special effort made by the Spanish parliament.
} 
them to deal with the negative externalities of their national policies effectively' (Jancic, $p$. 194). Briefly put, NPs do not have a strong incentive to comply with the European Semester because they are accountable to national constituencies and, accordingly, they struggle for explaining why they should take potential externalities into account. Maatsch has observed two parliamentary cycles of the European Semester (2014 and 2015), in Austria, France, Germany, and Ireland. But her analysis avoids the abstract reference to NPs and it revolves around the behaviour of parliamentary parties. The findings show that compliance with the European Semester is more likely when the political preferences of the parliamentary majority align with the recommendations of the Commission, while it is less likely when these preferences do not align and parliament has strong formal powers in budgetary and EU issues.

In an important chapter, Jancic addresses the crucial question of the political accountability of the European Central Bank. Given the role played by the ECB during and after the Euro emergency, the importance of this issue cannot be underestimated. Jancic compares the accountability of the ECB with that of the Japanese and the US central banks (based on legislation) and highlights its special contribution to the management of the Euro-crisis on a number of different levels. The activism of the ECB - which was undoubtedly the pivotal actor in swiftly reassuring markets of the sustainability of the EMU - and its President have triggered the concerns of both the European Parliament and many NPs. Concretely, the accountability independence of the ECB has been somehow relaxed: communication between parliaments and the ECB is augmented (both for monetary policy and prudential supervision). In particular, the President of the ECB has appeared in a number of plenary and committee sessions of NPs, but in a completely informal way. This activity resembles the political dialogue between the Commission and the NPs as initiated by the Barroso presidency: 'Through these practices the ECB is increasing the awareness, publicity and understanding of EU monetary policy. This is significant because it establishes a direct communication link between the EU'S monetary authority and domestic lawmakers [...] However, the nature of the dialogue between the ECB and NPs is essentially one of exchange of information and not of full-blown political control of the sort maintained between parliaments and governments' (Jancic, p. 154). These remarks qualify the nature of the intervention of NPs more in terms of communication function rather than deliberative or scrutiny. Such interaction has not been conflictual, but interestingly MPs (Pringle, Gauweiler) have at times used the judicial channel in order to challenge the legality of ECB's (or other EU institutions') behaviour during the crisis.

\section{From Institutions to Political Subjects}

Comparative research has shown that national parliaments occupy different positions within the European Union legal order and, of course, within their own national constitutional systems. ${ }^{7}$ For this reason, there is an increasing awareness that research on the roles and functions of NPs cannot but open up the black box of parliament as a formal institution in order to look at the substantial dynamics inside it. ${ }^{8}$ In other words, any analysis

\footnotetext{
${ }^{7}$ See the chapters devoted to each Member State in C. Neuhold, O. Rozenberg, J. Smith, C. Hefftler (eds), The Palgrave Handbook of National Parliaments and the EU, cit.

8 This remark had already been made several years ago by $\mathrm{P}$. Kiiver, The National Parliaments in the EU, Kluwer, The Hague, 2006.
} 
on the role of national parliaments should take into account the political subjects (parties, parliamentary groups and parliamentary officials) that animate its activities.

The volumes by Maatsch and Winzen make an important contribution on this point. Their research is interdisciplinary and combines legal analysis with statistical and comparative qualitative and quantitative political analysis. One of the peculiarities of the volume is that its focus is not only on a comparative review of NPs as single units within the wider European Union constitutional order. The approach includes the position of each NP within its own constitutional system, the formation of preferences of political parties and the power differential among NPs in the EU. Both authors provide precious information for confirming or not certain hypotheses concerning the current role of national parliaments. Maatsch reconstructs the behaviour, discourses and preferences of political parties during the crisis in both creditor Member States and indebted Member States. Her findings are troubling for the autonomy of NPs. In particular, the classic cleavage left-right, so central in budgetary issues, has not played a pivotal role during the votes on the economic governance. In her reading of the NPs behaviour, the dimensions that structured political conflicts were two: government versus opposition and pro- versus anti-EU. But in her qualitative analysis of parliamentary discourses, Maatsch found that there was not always an alignment between discourse and voting, in particular in bailout Member States. The latter distinction (together with the economic preferences of the political majority) explains also the macro-economic preferences adopted by NPs during the crisis. The autonomous political decisionmaking process of some NPs has been severely constrained by economic preconditions.

Winzen's book tackles with the ways NPs reacted to the new economic governance adaptation of NPs to the economic governance but it does so with the support of an empirical analysis and in the framework of a wider context which includes the factors of adaptability of NPs to European integration. The main thesis of the book is that the quality of rights of participation of NPs in EU affairs is usually determined by a series of factors among which national constitutional preferences are extremely relevant. Institutional structure is obviously important, but Winzen puts forward an argument based on empirical research for the importance of the expectations and the political cultures of national parties and their representatives. This is basically a call to take the study of parliamentary behaviour more seriously. National parliamentary politics in EU affairs is not a matter of sheer resignation before a rigid structure, but (as shown by in-depth analysis of the available data) it is determined by a number of variables which are deeply contextual. Crucial for the determination of NPs' reaction vis-à-vis changes dictated by integration or emergency are, on one hand, the institutional options available to the parliamentarians, and, on the other hand, the constitutional preferences of the parties, that is, whether they favour a federalist outlook or an intergovernmental one. ${ }^{9}$ The empirical chapters of this study investigates variations of changes in response to the deepening of European integration, with specific cases devoted to the development of oversight institutions (chapters 4 and 5) and the proposals for giving parliaments a direct European role (chapter 6). For the purposes of this review, two case studies illustrate the complexity (and relative unpredictability) of parliamentary behaviour in the context of the new economic governance. The design and the approval of the ESM represents the first one. The findings

\footnotetext{
${ }^{9}$ Strictly related to this distinction is the question whether parties prefer to focus on domestic oversight of EUrelated activities.
} 
of Winzen show that in this case the reaction of NPs to an intergovernmental Treaty which would constrain or limit some of their powers was mostly determined by the level of budgetary powers of NPs: in countries where parliaments have strong budgetary powers, the parliamentarians fought for acquiring strong rights in the ESM decision-making process (e.g., Austria, Germany, Netherlands). The other case is provided by art. 13 of the Fiscal Treaty which invites NPs and the EP to establish a joint conference monitoring the process of economic and budgetary policy-making. In this case, the differences in budgetary powers have not played the key role; rather, the attitude of parliamentarians toward this new avenue of interparliamentary cooperation has been partially determined by the domestic presence of strong oversight institutions. Such cooperation might indeed distract resources from a domestic focus on parliamentary rights in and beyond EU affairs. Winzen's conclusions is two-fold: there is still room for NPs active role in the EU integrated order, as shown by the emergence of EU-related oversight institutions in several Members States; on the other hand, opportunities have not been used in the same way across the European parliamentary spectrum. As the author explains, 'differences between parliaments are not a matter of accident or structural constraints. They result from political elites' ideas about what kind of democratic institutions and procedures the EU needs' (Winzen, p. 183). Existing institutions may work as constraints (as they did for the new economic governance), but they are often the outcome or the reflection of domestically consensual constitutional preferences.

Both Maatsch's and Winzen's results confirm that a proper understanding of parliamentary discourses and voting behaviour cannot but begin with a study of the preferences of political parties and the political culture of their members. Even in situations of emergency, where another variable is introduced in the picture, these factors remain decisive although they cannot explain everything - for the determination of parliamentary behaviour. In other words, the study of the reaction of NPs during the crisis cannot limit itself to the analysis of institutional interactions (vertically, with EU institutions, horizontally within national institutions or in the dialogue with other NPs).

\section{Building Parliamentary Capacity: Interparliamentary Cooperation}

Part III of the volume edited by Jancic highlights the strategic importance of interparliamentary cooperation in different ambits. ${ }^{10}$ In the chapters of this part, interparliamentary cooperation is read as a sign of resilience of the NPs. Cooper frames the forms and structures of current interparliamentary cooperation in terms of an emerging order. He recognises the tensions and conflicts that affect interparliamentary cooperation bodies but he identifies three emerging trends with ordering properties. The first trend is the functional drive of each interparliamentary cooperation forum. The CFSP-CDSP and the SECG conferences have been created as functionally specialised body and the incipient oversight mechanism for the political monitoring of Europol is inspired by the same logic. The second trend concerns how these new bodies should be organised and this task has been taken up by the EU Speakers conference. Finally, a third trend is visible in the logistical arrangements of these interparliamentary conferences, which has been managed by the rotating Presidency Parliament. These three trends counteract the inertial tendency toward

\footnotetext{
${ }^{10}$ For an extended analysis of interparliamentary cooperation see N. Lupo, C. Fasone (eds), Interparliamentary Cooperation in the EU Composite Constitution, Hart, Oxford, 2016.
} 
a disordered interaction in the history of interparliamentary cooperation and indicate, according to Cooper, a growing awareness of its importance among NPs. The other key area where policies of the EU are steadily increasing concerns the external powers.

In an exhaustive assessment, Kolja Raube and Jan Wouters cover three key segments of EU external action: Common Security and Foreign Policy, trade policies and human rights. In these three fields, NPs' resources and actions varied greatly from parliament to parliament. But despite an initial resignation to inaction, Raube and Wouters find that there has been an increasing organised reaction, at least when resources are available, from many NPs. For example, the rise of concerns for the ratification of complex and controversial free trade agreements has pushed several NPs to become more assertive and to push for the recognition of the agreements as a mixed agreement, so to be able to have a say on its final ratification. Venues for interparliamentary cooperation are less developed on these issues and, for trade policies and human rights, only COSAC has served at times as a site of cooperation and exchange of information. While the authors highlight the general strengthening of interparliamentary cooperation they also stress that it 'does at times lack the support of parliamentarians themselves, who do not regularly attend meetings or do not use the possibility to be represented by larger delegations. Moreover, interparliamentary cooperation in EU external relations currently does not go beyond networking and information exchange, which underlines its still rather informal character' (Jancic, p. 298).

In the final chapter of his edited volume, after an analysis of the 'third yellow card', Jancic suggests two possible avenues for the future involvement of national parliaments in European integration. The first one is to strengthen the oversight function of parliaments. This move is already underway, but it needs to be enhanced because, as remarked in several chapters, it is still far from being able to hold new intergovernmentalism accountable. The second, on which he particularly insists, is to enhance the available forms of interparliamentary cooperation under the assumption that only meaningful interaction among NPs can make any difference at the EU level. This might happen, perhaps, through an upgrade of cooperation by merging into a single body all interparliamentary forums (with functionally specialised working groups).

In light of the conclusions advanced by these three volumes, one might put into question the capacity of national parliaments to impress a trajectory on (or to influence) European integration. One of the observations that emerge by reading these works is that national parliaments have adapted to the changes imposed by the multiple crises affecting today's Europe. Resilience and/or adaptation are often mentioned by some authors to describe how national parliaments reacted. Yet, on the question whether this adaptation is just passive recognition of a state of affairs or it contains the seeds for a renewal of the parliamentary role in the EU, the jury is still out. However, it seems that a couple of observations can be confirmed. First, parliaments have been affected and have adapted with different degrees across the EU; second, they have often been either circumvented or (alternatively) nudged by other institutions, that is, they have rarely claimed their own political autonomy. This does not bode well for their political potential. In fact, this is reflected in the mixed prognoses formulated by the authors and editors of these volumes. Jancic, in the conclusive chapter of his edited collection, remarks that 'Parliaments' legislative powers have been replaced by a mechanism that steers their members away from politics and into the domain of technocracy [...] this means that resilience in procedural terms has been overshadowed by resignation cast by the impotence of NPs to bring influence directly to bear on EU 
policies' (Jancic, p. 308). Alexandra Maatsch presents a less pessimist prognosis. She claims that the findings of her analysis 'demonstrate that despite the limitation of formal powers and prioritarization of international responsibility among governing parties, national parliaments have not become mere talking shops' (Maatsch, p. 117). Coherently, she shows that there is still space for the deliberative qualities of parliaments, provided that parliamentary debate is not overcome by emergency politics. Accordingly, the problem with the new Euro governance is identified more in the emergency and unconventional procedures adopted by EU institutions rather than by its permanent impact: 'national parliaments' formal powers became restricted by national governments that frequently decided to approve anti-crisis measures with fast-track procedures [...] in particular, if a fasttrack procedure reduced or eliminated the standard number of plenary debates, parliamentary parties were deprived of a necessary institutional framework to fulfil their representative and control functions' (Maatsch, p. 116). Maatsch believes that parliaments are capable of a certain degree of institutional flexibility and much of their lasting relevance will depend on how they will adapt to the new economic governance. Perhaps, what is at stake here is not much the alleged potential flexibility of parliaments, but the framing of the new economic governance as exceptional. Yet, it would be possible to read the new economic governance in a continuum with the institutional setting created first by the Maastricht Treaty and then enhanced by the Lisbon treaty. Winzen's conclusions are more encouraging, as his reconstruction casts a more active light on the role played by NPs in European integration. Yet, he also concedes that there are substantial differences among NPs and some have performed way better than many others. In the case of the new economic governance, it is by no chance that parliaments of creditor States have on average been able to negotiate an increase of their parliamentary rights and those of debtor States have been less assertive.

A common assumption which pervades larges sections of research (and political action as well) is that the best NPs can obtain at this point in time is a form of adaptation which would preserve (under some form) the communicative and scrutiny functions of NPs in EU affairs. Executive federalism is taken to be an insurmountable horizon against which NPs can only try to adapt. NPs do not represent any longer the forum where political parties form their political will and impress it, as governing activity, upon other institutions.

A recent proposal for reform known as the 'green card', initially inspired by the cards potentially triggered by subsidiarity review, has elicited some hope for those who wish a revival of NPs' capacity of contributing to the definition of the political trajectory of integration. In the volume edited by Jancic, a chapter by Karolina Boronska-Hryniewiecka assesses the potential of this new instrument. The idea was initially formally introduced in a COSAC meeting in 2013 and has been subsequently developed by the Danish Folketing and the Dutch Tweede Kamer. ${ }^{11}$ The first trial green card was initiated by the House of Lords on the issue of food waste. A letter inviting the Commission to adopt a strategic approach to the reduction of food waste within the EU was sent with the signature of 16 out of the 41 national parliamentary chambers. The Commission responded to the Green Card in November of the same year and, when it published its Circular Economy Packaged, it included some of the suggestions coming from the NPs. However, the two following try-outs

\footnotetext{
${ }^{11}$ Not all parliaments have expressed their support. In fact, three chambers have made visible their opposition: the Finnish Eduskunta, the Italian Camera dei deputati, and the Romanian Senate. Moreover, according to a COSAC questionnaire, in Poland and Sweden this kind of parliamentary action could be incompatible with their constitutional framework.
} 
were not met by any significant reaction from European institutions. Whereas a significant minority of NPs have shown great enthusiasm for this instrument, Boronska-Hryniewiecka's clear analysis presents it as an ambiguous tool for parliamentary politics. In particular, the green card might be perceived by the EP as endangering its institutional position because it would grant the NPs an indirect legislative initiative. ${ }^{12}$ In light of the legal and political hurdles surrounding this instrument, her main suggestion is to turn the green card in an instrument for joint-amendment action. While initially limited in scope, this reform might have some potential on the basis of the possibility that interparliamentary cooperation, through learning and adjustment, would realistically pave the way in the future for a more assertive approach by NPs.

\section{Conclusion}

What is the political condition of NPs in the EU after the Lisbon Treaty and the Euro crisis? These three volumes all point to a particular dynamic: it has taken time for NPs to understand, first, how the new instruments introduced by the Lisbon Treaty could be employed and how to contain, after the Euro crisis, the expansion of the new intergovernmentalism. Common to all three books are the ideas that (1) at least the communication and the scrutiny functions have mostly been enhanced, while the others have on average suffered, and (2) that often these progresses have taken place in a very uneven manner, that is, more in some NPs than others. However, whether this will be enough to avoid further weakening of the role of NPs in EU policy making is far from certain.

\footnotetext{
12 In a comparative chapter of the volume edited by Jancic, Katarzyna Granat looks at the way in which the competition between the federal and the State level has been managed in Switzerland and the US, trying to extract some of their practices to be applied to the EU and the role of the NPs as the political safeguards of federalism.
} 